\title{
Detection of hemizygosity at the elastin locus by FISH analysis as a diagnostic test in both classical and atypical cases of Williams syndrome
}

\author{
Isabella Borg, Joy D A Delhanty, Michael Baraitser
}

\begin{abstract}
A small pilot study has been carried out in order to assess the reliability of the detection of hemizygosity at the elastin locus by fluorescence in situ hybridisation (FISH) analysis, as a diagnostic test in both classical and atypical cases of Williams syndrome (WS). Five subjects with WS and five others in whom a diagnosis could not be confirmed on clinical criteria alone were evaluated. Hemizygosity at the elastin locus by FISH analysis was detected in all classical Williams syndrome cases and in three of the five atypical subjects. Furthermore, a combination of a few specific facial features found to be present in all subjects with the elastin gene hemizygosity has been suggested to aid the index of clinical suspicion.
\end{abstract}

( $\mathcal{F}$ Med Genet 1995;32:692-696)

Williams syndrome (WS), a developmental disorder affecting connective tissue and the central nervous system, was first described in $1961^{1}$ and its incidence is estimated to be 1 in 20000 live births. It is almost always sporadic but there have also been a few reports of familial cases. ${ }^{2-4}$

The condition is characterised by distinctive facial features, heart defects, the commonest being supravalvular aortic stenosis (SVAS), growth delay, learning disabilities, mental retardation, unusual neurobehavioural features, and infantile hypercalcaemia. ${ }^{15-8}$ Preus $^{9}$ had described a "lacey" iris pattern as a diagnostic clue in infants, but Holmstrom et al ${ }^{10}$ reported only $51 \%$ of WS patients having this feature. The clinical diagnosis may be easy in the classical case but many patients cause diagnostic difficulty, especially in the early years of life; not only is the phenotype variable but it also changes with advancing age.

The diagnostic process has been helped by Ewart et $a l^{11}$ who showed by FISH and quantitative Southern analysis that complete deletion of one elastin allele causes WS and implicated elastin hemizygosity in the pathogenesis of the disease. The submicroscopic deletion, which was shown in all nine affected subjects studied, spans at least $114 \mathrm{~kb}$ within the chromosomal band $7 \mathrm{q} 11.23$ and extends beyond the elastin gene. It is now known that the deletions span at least $250 \mathrm{~kb},{ }^{12}$ presumably disrupting ad- jacent as yet unidentified genes. Hemizygosity of the elastin gene could account for all connective tissue abnormalities seen in Williams syndrome.

The aims of the present study are twofold; first, to establish whether detection of hemizygosity at the elastin locus by FISH analysis is a reliable and accurate test for the diagnosis of WS in both classical and atypical cases and, secondly, to establish a few easy clinical criteria that would aid the index of clinical suspicion of the condition with the consequent possibility of an early diagnosis of WS.

\section{Methods}

SUBJECTS

The names of 20 patients with classical Williams syndrome were randomly selected from the patients' register at the Institute of Child Health (ICH), London. Photographs, taken during their last visit to the genetics clinic up to 11 years previously, were reviewed, as were their case histories. Ten patients were considered for inclusion in this study. The criteria upon which patients were selected were based on the presence of a combination of six dysmorphic features (periorbital fullness, broad nasal tip, anteverted nares, sagging cheeks, full lower lip, and open mouth appearance). The diagnoses were counterconfirmed by two consultant clinical geneticists. No criteria were used in the selection of sex or age of the subjects. Only five of the 10 patients were eventually studied, as one was at college, one other was not made aware of the diagnosis by her parents, one was being studied elsewhere, one refused, and another did not keep the clinic appointment. The five study patients comprised four males and one female with an age range of 6 years to 19 years. Permission to contact the patients was sought from their general practitioner and consent was obtained from the parents.

Atypical patients were selected by two methods. Four patients were selected in whom the diagnosis of WS had been considered but a definitive diagnosis of the condition could not be established at their last visit to the genetics clinic. Their earlier photographs and case histories were reviewed as for the typical cases. Nine other patients were seen as referrals from various clinical sources; in only one of these was a diagnosis of WS considered. Thus, only five atypical patients were eventually stud- 
Table 1 Summary of phenotypic and laboratory findings of atypical cases

\begin{tabular}{|c|c|c|c|c|c|}
\hline & Case & & & & \\
\hline & 1 & 2 & 3 & 4 & 5 \\
\hline $\begin{array}{l}\text { Present age } \\
\text { Developmental delay }\end{array}$ & 2 y $4 \mathrm{mth}$, & 6 y $10 \mathrm{mth}$ & $15 \mathrm{y}$ & 2 y $3 \mathrm{mth}$ & $9 \mathrm{y}$ \\
\hline $\begin{array}{l}\text { Developmental delay } \\
\text { Hoarse voice }\end{array}$ & + & $\begin{array}{l}+ \\
+\end{array}$ & $\stackrel{+}{-}$ & $\begin{array}{l}+ \\
+\end{array}$ & $\begin{array}{l}+ \\
+\end{array}$ \\
\hline Birth weight & $\begin{array}{l}2750 \mathrm{~g} \text { at } 36 / 40 \text { gestation } \\
\text { (50th centile) }\end{array}$ & $\begin{array}{l}2000 \mathrm{~g} \text { at } 38 / 40 \text { gestation } \\
\text { (<3rd centile) }\end{array}$ & $\begin{array}{l}3500 \mathrm{~g} \text { at term } \\
(50 \text { th centile) }\end{array}$ & $\begin{array}{l}2240 \mathrm{~g} \text { at } 38 / 40 \text { gestation } \\
(<3 \text { rd centile) }\end{array}$ & $\begin{array}{l}2580 \mathrm{~g} \text { at } 38 / 40 \text { gestation } \\
\text { ( }<3 \text { rd centile) }\end{array}$ \\
\hline Present weight & $<3$ rd centile & NA & $>25$ th centile & $<3$ rd centile & $>25$ th centile \\
\hline Present height & $<3$ rd centile & NA & 50th centile & $<3$ rd centile & $<3$ rd centile \\
\hline Present OFC & 3rd centile & NA & $<50$ th centile & $<3$ rd centile & 3rd centile \\
\hline $\begin{array}{l}\text { Broad forehead } \\
\text { Medial eyebrow flare }\end{array}$ & 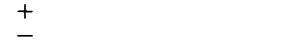 & 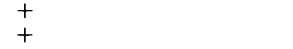 & $\begin{array}{l}- \\
-\end{array}$ & + & \pm \\
\hline Periorbital fullness & 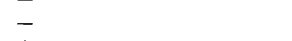 & (n) & $\begin{array}{l}- \\
-\end{array}$ & $\overline{+}$ & $\bar{t}$ \\
\hline Epicanthic folds & + & + & - & + & + \\
\hline Stellate irides & - & + & - & - & + \\
\hline Strabismus & - & - & - & - & + \\
\hline $\begin{array}{l}\text { Malar hypoplasia } \\
\text { Sagging cheeks }\end{array}$ & - & + & + & + & + \\
\hline Before & - & + & - & No record & No record \\
\hline $\begin{array}{l}\text { At present } \\
\text { Nose }\end{array}$ & - & + & - & + & + \\
\hline $\begin{array}{l}\text { Nose } \\
\text { Short }\end{array}$ & + & + & - & + & \\
\hline $\begin{array}{l}\text { Short } \\
\text { Broad tip }\end{array}$ & + & + & + & $\begin{array}{l}+ \\
+\end{array}$ & $\begin{array}{l}+ \\
+\end{array}$ \\
\hline Anteverted nares & + & + & + & + & $\begin{array}{l}+ \\
+\end{array}$ \\
\hline Philtrum & & & & & \\
\hline Long & + & - & - & + & - \\
\hline Smooth & + & + & - & - & + \\
\hline Full/arched upper lip & + & + & + & + & - \\
\hline $\begin{array}{l}\text { Full lower lip } \\
\text { Mouth }\end{array}$ & + & + & + & + & + \\
\hline Open & + & + & - & + & + \\
\hline Wide & $\overline{1}$ & + & + & - & + \\
\hline Dental anomalies & Microdontia & Splayed out & Crowded & - & $\begin{array}{l}\text { Irregular, caries, } \\
\text { malocclusion }\end{array}$ \\
\hline Chin & & & & & \\
\hline $\begin{array}{l}\text { Small } \\
\text { Pointed }\end{array}$ & $\begin{array}{l}- \\
-\end{array}$ & $\begin{array}{l}+ \\
+\end{array}$ & $\begin{array}{l}- \\
-\end{array}$ & $\bar{t}$ & $\overline{-}$ \\
\hline Ear anomalies & $\overline{-}$ & Right cup shaped ear & $\begin{array}{l}\text { Incompletely folded } \\
\text { helices }\end{array}$ & - & - \\
\hline Long neck & - & - & - & - & - \\
\hline Sloping shoulders & - & $\bar{S}$ tort 5th MC & - & - & - \\
\hline Skeletal anomalies & - & $\begin{array}{l}\text { Short 5th MC } \\
\text { Dislocatable R knee joint }\end{array}$ & $\begin{array}{l}\text { Broad flattened thumbs, } \\
\text { prominent proximal } \\
\text { interphalangeal joints }\end{array}$ & Mitusys - & $\begin{array}{l}\text { Short } 4 \text { th \& } 5 \text { th MC, } \\
\text { clinodactyly L 4th \& } 5 \text { th } \\
\text { fingers, laxity of elbows, } \\
\text { hemivertebra L2 with } \\
\text { marked kyphosis, } \\
\text { dysraphism LS }\end{array}$ \\
\hline Cardiac anomalies & - & $\begin{array}{l}\text { Coarctation of aorta, } \\
\text { hypoplastic aortic arch, } \\
\text { HOCM, PDA }\end{array}$ & Bicuspid aortic valve & $\begin{array}{l}\text { Mild SVAS } \\
\text { R pulmonary artery } \\
\text { stenosis }\end{array}$ & VSD \\
\hline Renal anomalies & - & $\mathrm{L}$ agenesis & - & - & - \\
\hline Past medical history & $\begin{array}{l}\text { FTT, feeding problems, } \\
\text { hypercalcaemia, } \\
\text { intussusception, } \\
\text { intestinal malrotation }\end{array}$ & $\begin{array}{l}\text { FTT, feeding problems, } \\
\text { hypercalcaemia, } \\
2 \text { cardiac arrests, } \\
\text { L undescended testis, } \\
\text { "glue ears", chest } \\
\text { infections (rec) }\end{array}$ & FTT & $\begin{array}{l}\text { Feeding problems, reflux } \\
\text { oesophagitis, pyloric } \\
\text { stenosis }\end{array}$ & $\begin{array}{l}\text { Chest infections, } \\
\times 2 \text { spinal fusions }\end{array}$ \\
\hline Present medical history & $\begin{array}{l}\text { Recurrent respiratory } \\
\text { infections }\end{array}$ & $\begin{array}{l}\text { Recurrent respiratory } \\
\text { infections, delayed } \\
\text { speech } \downarrow R \text { renal function }\end{array}$ & Nil & Nil & $\begin{array}{l}\text { Mild spinal cord } \\
\text { compression. Cyanosis } \\
\text { after long walks }\end{array}$ \\
\hline $\begin{array}{l}\text { Karyotype } \\
\text { FISH 7q11.23 }\end{array}$ & $\begin{array}{l}46, \mathrm{XX} \\
\text { Not deleted }\end{array}$ & $\begin{array}{l}46, X Y \\
\text { Deleted }\end{array}$ & $\begin{array}{l}46, \mathrm{XY} \\
\text { Not deleted }\end{array}$ & $\begin{array}{l}46, X Y \\
\text { Deleted }\end{array}$ & $\begin{array}{l}46, \mathrm{XX} \\
\text { Deleted }\end{array}$ \\
\hline
\end{tabular}

+ present, - not present, NA not assessed, N normal, L left, R right, OFC occipitofrontal circumference, FTT failure to thrive, MC metacarpal bones, L2 second lumbar vertebra, LS lumbar spine, PDA patent ductus arteriosus, HOCM hypertrophic cardiomyopathy, VSD ventricular septal defect, SVAS supravalvular aortic
stenosis.

ied, two of whom were females and three were males with an age range of 2 years to 15 years. All 10 patients were white.

\section{CYTOGENETIC STUDIES}

In all subjects, chromosomes were cultured from peripheral blood using conventional methods and the $G$ banded metaphase chromosomes were then analysed for structural chromosome abnormalities. This was followed by FISH analysis of metaphase chromosomes using the Elastin Williams Syndrome Chromosome Region (WSCR) digoxigenin labelled probe with D7S427 chromosome 7 control probe (Oncor $\left.{ }^{\circledR}\right)$. The method used was that recommended by the manufacturer but with some slight alterations. A minimum of $10 \mathrm{me}-$ taphases per patient was scored for the presence or absence of paired signals on both homologues for each of the probes. Slides were viewed and scored on a Nikon Optiphot mi- croscope equipped for fluorescence and images captured on an MRC 600 (Biorad) confocal laser microscope attachment.

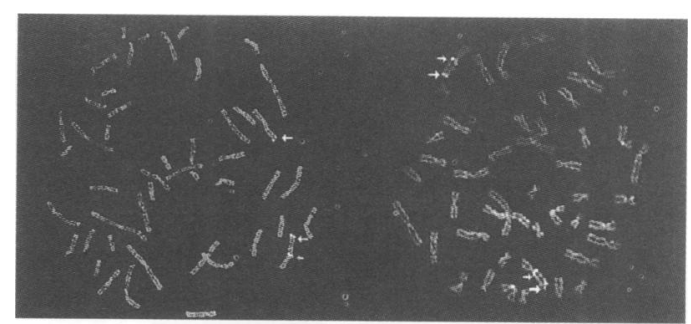

Figure 1 (Left) Metaphase chromosome spread of case 10 after FISH showing a fluorescent signal on one of the chromosome 7 homologues at $7 q 11.23$ (small arrow) and a fluorescent signal at $7 q 36$ on both homologues (large arrows. (Right) Metaphase chromosome spread of case 1 after FISH showing a fluorescent signal on both chromosome 7 homologues at 7911.23 (small arrows) and at 7q36 loci (arge arrows). Chromosomes were stained with propidium iodide and signals were detected with fluorescein isothiocyanate. 
Table 2 Summary of phenotypic and laboratory findings of typical cases

\begin{tabular}{|c|c|c|c|c|c|}
\hline & \multicolumn{5}{|l|}{ Case No } \\
\hline & 6 & 7 & 8 & 9 & 10 \\
\hline Present age & 11 y $2 \mathrm{mth}$ & 6 y $5 \mathrm{mth}$ & 6 y 6 mth & $19 y$ & $16 y$ \\
\hline $\begin{array}{l}\text { Developmental delay } \\
\text { Hoarse voice }\end{array}$ & $\begin{array}{l}+ \\
+\end{array}$ & $\begin{array}{l}+ \\
+\end{array}$ & $\begin{array}{l}+ \\
+\end{array}$ & $\begin{array}{l}+ \\
+\end{array}$ & + \\
\hline $\begin{array}{l}\text { Hoarse voice } \\
\text { Birth weight }\end{array}$ & $\stackrel{+}{2780} \mathrm{~g}$ at $41 / 40$ gestation & $\stackrel{+}{2610} \mathrm{~g}$ at term & $\stackrel{+}{1800 \mathrm{~g} \text { at } 36 / 40 \text { gestation }}$ & $\stackrel{+}{2800 \mathrm{~g} \text { at term }}$ & $\stackrel{+}{3000 \mathrm{~g} \text { at } 42 / 40 \text { gestation }}$ \\
\hline Dirtn weignt & (<3rd centile) & (<3rd centile) & (<3rd centile) & (<3rd centile) & $\begin{array}{l}3000 \mathrm{~g} \text { at } 42 / 40 \text { gestation } \\
\text { (3rd centile) }\end{array}$ \\
\hline Present weight & $>75$ th centile & $>3$ rd centile & $<3$ rd centile & $>10$ th centile & $<3$ rd centile \\
\hline $\begin{array}{l}\text { Present height } \\
\text { Present OFC }\end{array}$ & $<3$ rd centile & $>25$ th centile & $<3$ rd centile & $>10$ th centile & $<3$ rd centile \\
\hline Broad forehead & > 3rd centile & $\begin{array}{l}>3 \text { rd centile } \\
+\end{array}$ & $\begin{array}{l}\text { >3rd centile } \\
+\end{array}$ & $<3$ rd centile & $<3$ rd centile \\
\hline Medial eyebrow flare & + & + & - & $\overline{+}$ & $\begin{array}{l}+ \\
+\end{array}$ \\
\hline Periorbital fullness & + & + & + & + & + \\
\hline Epicanthic folds & - & - & + & - & + \\
\hline Stellate irides & + & - & + & + & + \\
\hline Strabismus & + & - & + & - & + \\
\hline $\begin{array}{l}\text { Malar hypoplasia } \\
\text { Sagging cheeks }\end{array}$ & + & + & + & + & + \\
\hline \multicolumn{2}{|l|}{ Sagging cheeks } & & + & + & + \\
\hline At present & + & + & + & - & $\stackrel{+}{-}$ \\
\hline \multicolumn{6}{|l|}{ Nose } \\
\hline Short & + & + & + & - & + \\
\hline Broad tip & + & + & + & + & + \\
\hline $\begin{array}{l}\text { Anteverted nares } \\
\text { Philtrum }\end{array}$ & + & + & + & + & + \\
\hline \multicolumn{4}{|l|}{ Philtrum } & + & + \\
\hline Smooth & + & + & + & + & + \\
\hline Full/arched upper lip & + & + & - & - & + \\
\hline $\begin{array}{l}\text { Full lower lip } \\
\text { Mouth }\end{array}$ & + & + & + & + & + \\
\hline $\begin{array}{l}\text { Mouth } \\
\text { Open }\end{array}$ & + & + & + & + & + \\
\hline $\begin{array}{l}\text { Upen } \\
\text { Wide }\end{array}$ & + & + & $\begin{array}{l}+ \\
+\end{array}$ & $\begin{array}{l}+ \\
+\end{array}$ & $\begin{array}{l}+ \\
+\end{array}$ \\
\hline Dental anomalies & Enamel hypoplasia & $\begin{array}{l}\text { Enamel hypoplasia, } \\
\text { caries }\end{array}$ & Microdontia, caries & - & - \\
\hline \multicolumn{6}{|c|}{ (1) } \\
\hline $\begin{array}{l}\text { Small } \\
\text { Pointed }\end{array}$ & $\begin{array}{l}+ \\
+\end{array}$ & + & + & $\begin{array}{l}+ \\
+\end{array}$ & + \\
\hline $\begin{array}{l}\text { Pointed } \\
\text { Ear anomalies }\end{array}$ & $\begin{array}{l}+ \\
-\end{array}$ & $\stackrel{+}{-}$ & \pm & $\stackrel{+}{\text { Simple helices }}$ & $\stackrel{+}{-}$ \\
\hline Long neck & - & - & - & + & + \\
\hline Sloping shoulders & + & - & - & + & + \\
\hline Skeletal anomalies & $\begin{array}{l}\text { Bil 5th finger } \\
\text { clinodactyly, spindle } \\
\text { shaped fingers, short } 4 \text { th } \\
\& \text { th } M C \text {, restricted } \\
\text { sup/pronation of elbows }\end{array}$ & $\begin{array}{l}\text { Bil 5th finger } \\
\text { clinodactyly }\end{array}$ & $\begin{array}{l}\text { Bil 5th finger } \\
\text { clinodactyly, } \\
\text { thoracolumbar scoliosis }\end{array}$ & $\begin{array}{l}\text { Bil 5th finger } \\
\text { clinodactyly, short } 4 \text { th \& } \\
\text { 5th MC }\end{array}$ & $\begin{array}{l}\text { Short 4th \& } 5 \text { th } M C \text {, } \\
\text { laxity of interphalangeal } \\
\text { joints, pectus carinatum }\end{array}$ \\
\hline Cardiac anomalies & SVAS & $\begin{array}{l}\text { SVAS, pulmonary valve } \\
\text { stenosis, bilateral } \\
\text { pulmonary aa stenosis, } \\
\text { multiple peripheral } \\
\text { pulmonary artery } \\
\text { stenosis with post } \\
\text { stenotic dilatation }\end{array}$ & Very small VSD & Mild SVAS & $\begin{array}{l}\text { Small supravalvular } \\
\text { pulmonary stenosis, } \\
\text { stenosis of origin of } \mathrm{L} \\
\text { subclavian artery, } \\
\text { stenosis of L upper } \\
\text { branch of pulmonary } \\
\text { artery, coarctation of } \\
\text { abdominal aorta }\end{array}$ \\
\hline Renal anomalies & QT & TMTT & $n^{\prime}$ & $\begin{array}{l}\mathrm{R} \text { hydronephrosis, } \mathrm{R} \\
\text { pelviureteric junction } \\
\text { obstruction }\end{array}$ & $\begin{array}{l}\text { ?R renal artery stenosis } \\
\text { (under investigation) }\end{array}$ \\
\hline Past medical history & $\begin{array}{l}\text { Neonatal jaundice, } R \\
\text { pneumonia, L inguinal } \\
\text { hernia repair, Ts/Ad } \& \\
\text { bilateral myringotomies }\end{array}$ & $\begin{array}{l}\text { FTT, biliary hypoplasia } \\
\& \text { hepatomegaly, otitis } \\
\text { media, chest infections }\end{array}$ & $\begin{array}{l}\text { Bilateral inguinal } \\
\text { hernias, undescended } \mathrm{R} \\
\text { testis, large hiatus } \\
\text { hernia, feeding } \\
\text { problems, FTT, } \\
\text { pyloroplasty, } \\
\text { intussusception, UTIs }\end{array}$ & $\begin{array}{l}\text { Neonatal jaundice, } \\
\text { Ramsted operation for } \\
\text { persistent vomiting, } \\
\text { bilateral inguinal hernias, } \\
\text { R pyeloplasty, recurrent } \\
\text { UTIs }\end{array}$ & $\begin{array}{l}\text { Severe birth asphyxia, } \\
\text { FTT }\end{array}$ \\
\hline Present medical history & Frequency of micturition & Nil & Epilepsy & $\begin{array}{l}\text { Recurrent UTIs (on } \\
\text { prophylactic treatment) }\end{array}$ & Nil \\
\hline $\begin{array}{l}\text { Karyotype } \\
\text { FISH 7q11.23 }\end{array}$ & $\begin{array}{l}\text { 46,XX } \\
\text { Deleted }\end{array}$ & $\begin{array}{l}46, \mathrm{XY} \\
\text { Deleted }\end{array}$ & $\begin{array}{l}46, \mathrm{XY} \\
\text { Deleted }\end{array}$ & $\begin{array}{l}\text { 46,XY } \\
\text { Deleted }\end{array}$ & $\begin{array}{l}46, \mathrm{XY} \\
\text { Deleted }\end{array}$ \\
\hline
\end{tabular}

+ present, - not present, OFC occipitofrontal diameter, FTT failure to thrive, MC metacarpal bone, VSD ventricular septal defect, SVAS supravalvular aortic

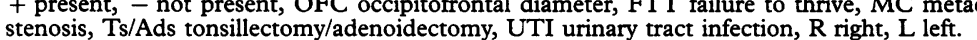

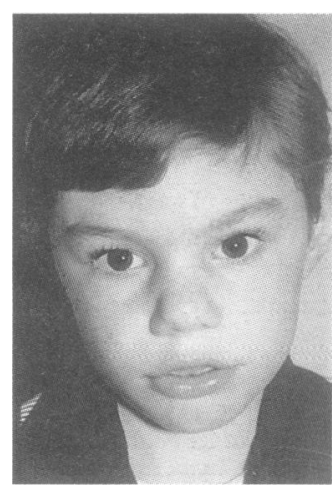

Figure 2 Case 3 aged 4 years.

\section{Results}

All the clinical and laboratory findings are summarised in tables 1 and 2 . No chromosomal aberrations were detected by $\mathrm{G}$ banding (QAS 4-6). Metaphases from patients showing hemizygosity at the elastin locus (signals on one homologue only at WSCR in the presence of control signals on both chromosomes) (fig 1) were $100 \%$ concordant in all cases.

\section{Discussion}

To date, published data have shown that all typical WS patients have the microdeletion at the elastin gene locus. In this small pilot study, all five cases in whom a confident diagnosis had been established, were found to have a submicroscopic deletion at 7q11.23 with FISH analysis. More interestingly, out of the five atypical cases, in whom a definitive diagnosis could not be made on clinical features alone, three were found to have the submicroscopic deletion at the elastin locus.

Establishing a diagnosis in the neonatal period and in infancy can sometimes be difficult. Burns et $a l^{13}$ noted that many patients with WS are not diagnosed until they are old enough to show the characteristic personality and facial changes. Moreover, a number of these changes are subtle and might not be present in all affected subjects. In our study, patient 3 (fig 2) had reached 15 years of age before the diagnosis of Williams syndrome was excluded. Another atypical case, patient 5 (fig 3 ), who was found to have the deletion, had only been suspected of having the condition while this study was in progress. She had reached her ninth birthday and other possible diagnoses that had been considered by the 


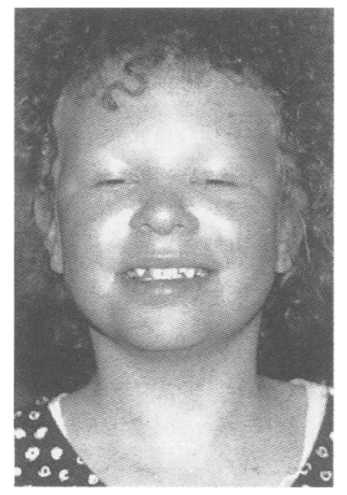

Figure 3 Case 5 aged 9 years.

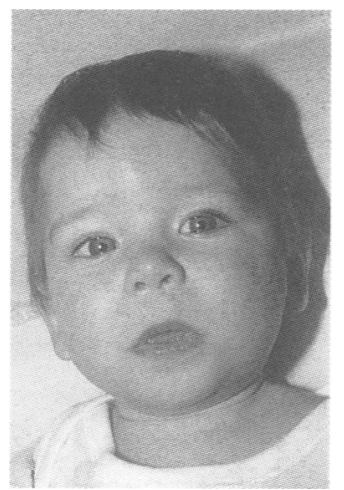

Figure 4 Case 1 aged 10 months.

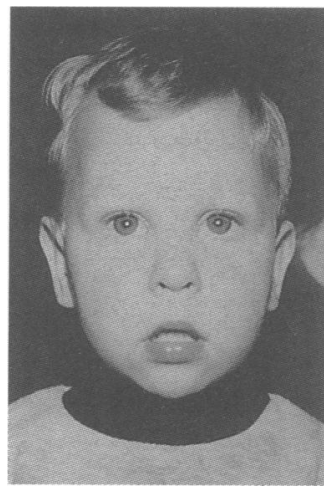

Figure 7 Case 4 aged 2 years. referring doctor were Down's and Albright's syndromes.

In this study (age range 3.25-19 years), correlation of the laboratory results with the clinical findings suggested a number of facial features that are found in all the subjects showing the elastin gene deletion. These features were periorbital fullness, malar hypoplasia, sagging cheeks in infancy and childhood, thin cheeks in adolescence or in early adulthood, broad nasal tip with anteverted nares, full lower lip and an open mouth appearance. In retrospect, it might have been possible to predict which of the five atypical cases would have the submicroscopic deletion based on these features rather than the facial gestalt, which was not totally characteristic. Indeed, patients 1 (fig 4) and 3 (fig 2) who did not have the chromosomal deletion did not have this combination of features. In addition, a history of a low birth weight, feeding problems, a heart murmur, a hoarse cry or voice, and delayed developmental milestones were common findings in the histories of all eight patients with the submicroscopic deletion. Much emphasis has been placed on the presence of clinical features, such as stellate irides, supravalvular aortic stenosis, hypercalcaemia, and loquacity, that their partial or complete absence in any one person has occasionally discouraged paediatricians from considering a diagnosis of WS. None of these was a constant feature in the eight cases with the submicroscopic deletion.

Some of the clinical features present in the eight patients with the deletion are unusual. These are a cupped ear and hypertrophic obstructive cardiomyopathy in patient 2 (fig 5), a prominent thyroid cartilage in patients 9 and 10 (fig 6), complete dysraphism of the lumbar spine and a hemivertebra at L2 in patient 5 (fig 3), pectus carinatum in patient 10 (fig 6), biliary hypoplasia in patient 7 , a large hiatus hernia in patient 8 , and pyloric stenosis in patients 4 (fig 7) and 8. Pyloric stenosis had been described by Morris $e t a^{14}$ as a feature in one of the patients with the $t(6 ; 7)(p 21.1$; q11.23) balanced reciprocal translocation. Patient 6 was born with bilateral contractures of all the fingers and, although previously described, ${ }^{15}$ this is a rare feature of the condition. In this study, seven out of the eight patients with the $7 \mathrm{q} 11.23$ deletion were found to have some degree of skeletal abnormality.
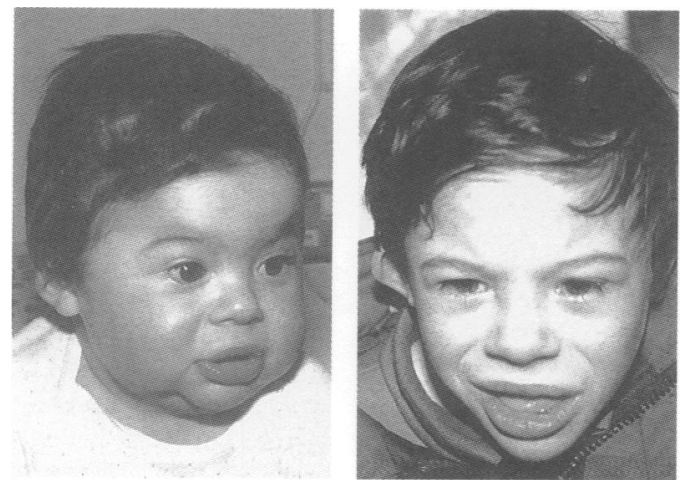

Figure 5 Case 2 aged 10 months and 6 years.
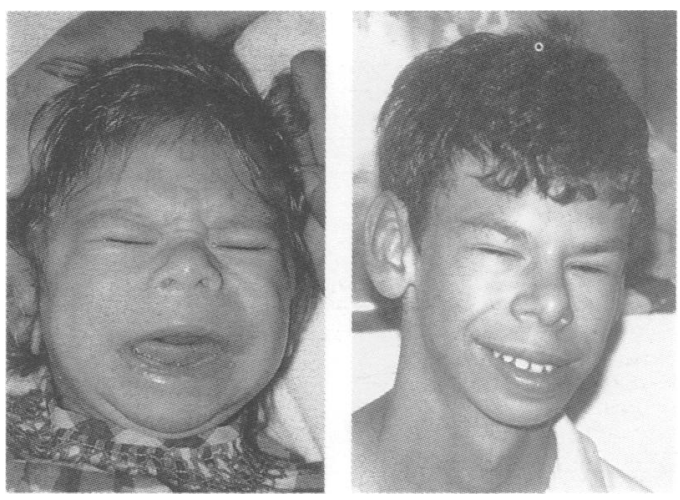

Figure 6 Case 10 aged 4 years and 16 years. This is a classical case of WS.

The prominence of the thyroid cartilage with increasing age is interesting and is possibly because of loss of subcutaneous tissue. The thinning of the cheeks (with loss of jowls) with advancing age (fig 6) would also be explained by the latter mechanism. A friendly disposition was a feature found in all the patients with the microdeletion but the degree of loquacity decreased as the severity of mental retardation increased. Similarly, hyperacusis was also a constant feature especially in the younger age group but parents often reported that the problem disappeared if the child was allowed to produce the noise itself and, also, with increasing age. Hypercalcaemia, a feature commonly described in the classical cases of WS, was documented in only two of the patients with the submicroscopic microdeletion. On the other hand, hypercalcaemia had been documented in both patients lacking this chromosomal abnormality.

The clinical observations noted in this small pilot study and elsewhere emphasise the need for more detailed phenotypic studies in patients and their families. Such studies should lead to the identification of the full spectrum of the features resulting from the deletion of an elastin gene. The size of the deletion would then be investigated by molecular studies and this subsequently correlated to the severity of the presenting clinical features. Those features not explained by the deletion of the elastin gene should be further investigated for other candidate genes that are possibly involved in the aetiology of WS.

The FISH analysis confirmed the diagnosis in all classical cases of WS and, therefore, on present evidence is an excellent diagnostic test. It is also extremely helpful in those cases where the diagnosis is uncertain but only larger studies would confirm this. This study has been done using lymphocytes but there is no reason why the technology cannot be extended for prenatal diagnosis. However, given the small recurrence risk, in most clinical situations the uptake for prenatal testing is likely to be small.

We would like to thank the patients and their parents for their cooperation in this study. We also thank the staff of the research
and clinical cytogenetics laboratories at the Genetics Department, UCL, for general help with this study. The confocal laser microscopic attachment was provided by the Medical Research Council as part of the Human Genome Medical project. 
1 Williams JCP, Barratt-Boyes BG, Lowe JB. Supravalvular aortic stenosis. Circulation 1961;24:1311-18.

2 Schmidt MA, Ensing GJ, Michels VV, Carter GA, Hagle DJ, Feldt RH. Autosomal dominant supravalvular aortic tenosis: large three generation family. Am $\mathcal{F}$ Med Gene 1989;32:384-9.

3 Morris CA, Thomas IT, Greenberg F. Williams syndrome: autosomal dominant inheritance. Am $\mathcal{F}$ Med Genet 1993; 47:478-81.

4 Sadler LS, Robertson LK, Verdaasdonk KR, Gingell R. The Williams syndrome: evidence of possible autosomal dominant inheritance. Am 7 Med Genet 1993;47:468-70.

5 Beuren AJ, Apitz J, Harmjanz D. Supravalvular aortic stenosis in association with mental retardation and certain facial appearance. Circulation 1962;26:1235-40.

6 Burn J. Syndrome of the month. Williams syndrome. $f$ Med Genet 1986;23:389-95.

7 Greet Greenberg F, Ledbetter DH. Chromosome abnormalities and Willams syndrome. Am $\mathcal{F}$ Med Genet 1988;30:993-4.

8 Morris CA, Demsey SA, Leonard CO, Dilts C, Blackburn BL. Natural history of Williams syndrome: physical characteristics. $\mathcal{F}$ Pediatr 1988;113:318-26.
9 Preus $M$. Iris pattern in patients with the Williams syndrome. f Pediatr 1975;87:840.

10 Holmstrom G, Almond G, Temple K, Taylor D, Baraitser $M$. The iris in Williams syndrome. Arch Dis Child 1990; 65:987-9.

11 Ewart AK, Morris CA, Atkinson D, et al. Hemizygosity at the elastin locus in a developmental disorder, Williams syndrome. Nature Genet 1993;5:11-16.

12 Ewart AK, Jin W, Atkinson D, Morris CA, Keating MT. Supravalvular aortic stenosis associated with a deletion disrupting the elastin gene. $f$ Clin Invest 1994:93. 1071-7.

13 Burns MA, McLeod R, Linton LR, Butler MG. Metacarpophalangeal pattern profile analysis in Williams syndrome. Am $₹$ Med Genet 1993;47:471-4.

14 Morris CA, Loker J, Ensing G, Dean Stosk A. Supravalvular aortic stenosis cosegregates with a familial 6;7 translocation which disrupts the elastin gene. Am $\mathcal{F}$ Med Genet 1993;46:737-44.

15 Kaplan P, Kirschner M, Watters G, Costa MT. Contractures in patients with Williams syndrome. Pediatrics 1989;84: 895-9. 